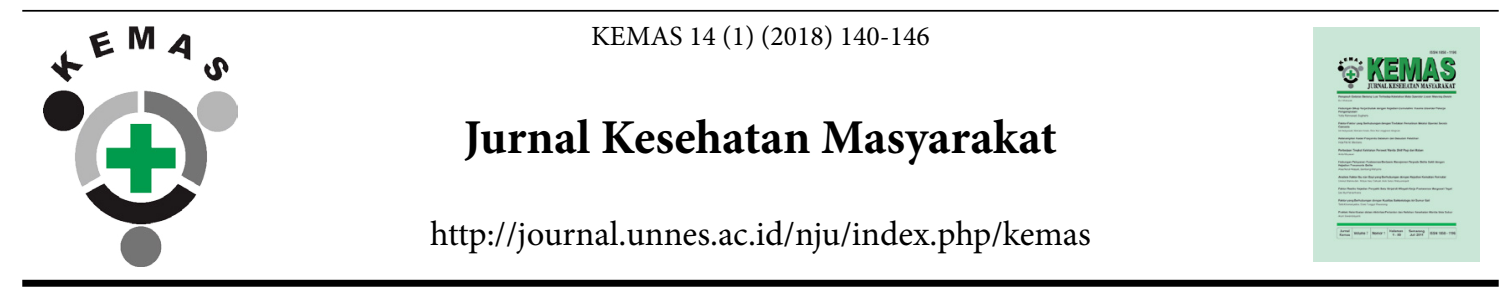

\title{
Iodine Consumption and Linear Growth of Children Under Five Years Old in Malabero Coastal Area, Bengkulu City
}

\author{
Demsa Simbolon $^{1 凶}$, Tri Hapsari ${ }^{1}$ \\ ${ }^{1}$ Nutrition Major, Poltekkes Kemenkes Bengkulu, Indonesia
}

\begin{tabular}{l} 
Article Info \\
\hline Article History: \\
Submitted January 2018 \\
Accepted April 2018 \\
Published July 2018 \\
\hline Keywords: \\
Children under five \\
year old, linear growth, \\
stunting, iodine \\
\hline DOI \\
https://doi.org/10.15294/ \\
kemas.v14i1.13005
\end{tabular}

\begin{abstract}
The high prevalence of stunting is influenced by nutritional intake. Iodine is an important micronutrient for growth. Bengkulu City is located along coastal area, hence it has potentially high iodine food sources. However, stunting prevalence was still high. This was a cross-sectional study conducted from March to July 2016 which aimed to determine the relationship between iodine consumption and linear growth of children under five years old in Malabero coastal area of Bengkulu City. The population were children aged 2-5 years old with a sample of 73 children. Measurement of linear growth was based on AHZ index using microtoice with capacity of $200 \mathrm{~cm}$ and accuracy of $0.1 \mathrm{~cm}$. Iodine intake was measured based on semiquantitative Food Frequency Questionnaire (FFQ). The results showed that $71.2 \%$ of children under five years old did not had sufficient iodine consumption with average percentage of iodine sufficiency $47.7 \% \pm 0.456$. There were $53.5 \%$ of children under five years old who experienced stunting. Low iodine consumption was shown to be associated with stunting. There were $73.1 \%$ children under five years old with insufficient iodine intake who were stunted while only $4.8 \%$ children under five years old with sufficient iodine intake who were stunted.
\end{abstract}

\section{Introduction}

Children under five years old undergoes rapid growth and development. It is a golden period or critical period which determine their quality of life. Growth and development disorders in this age group could cause lost generation problem (Welasasih \& Wirjatmadi, 2012). One of growth disorder problem in children under five years old is linear growth disorder (stunting). Stunting or short stature is a linear growth disorder which is extensively used to measure individual or public nutritional status. United States National Center of Health Statistics (NCHS) defined malnutrition as linear growth whch do not reach average growth of particular age and gender group (Sudiman, 2008). Management of linear growth disorder is one of the four priority programs in health development which were written in primary objective of Intermediate Term Development Plan of 2015-2019. The target is to decrease stunting prevalence (short stature and very short stature) in children under two years old up to $28 \%$ (Kementerian Kesehatan RI, 2017).

Short stature among children under five years old indicates the presence of chronic nutritional problems. It was estimated that there were 162 million children under five years

\footnotetext{
Correspondence Address:

Nutrition Major, Poltekkes Kemenkes Bengkulu, Indonesia

Email : demsa_ui03@yahoo.com
} 
old with short stature in 2012. If the trend is allowed to continue, it is projected to become 127 million in 2025. Around 56\% stunted children lived in Asia and 36\% lived in Africa. The percentage of children under five years old with short stature nutritional status (short and very short) in Indonesia in 2013 was $37.2 \%$. When compared to the percentage in 2010 (35.6\%) and 2007 (36.8\%), the number did not show significant decrease/improvement. The highest percentage in 2013 were in East Nusa Tenggara Province (51.7\%), West Sulawesi Province $(48.0 \%)$, and West Nusa Tenggara Province (45.3\%), while the lowest percentage were in Riau Islands Province (26.3\%), Yogyakarta Special Region (27.2\%), and Jakarta Special Capital Region (27.5\%) (Kementerian Kesehatan RI, 2017).

WHO stated that the prevalence of children under five years old with short stature would become public health problem when the prevalence reaches $20 \%$ or more (WHO, 2010). According to that standard, the prevalence of children under five years old with short stature in Indonesia is still high and considered as health problem that must be managed. The result of Nutrition Status Monitoring (2016) conducted by Kementerian Kesehatan RI found that $29 \%$ of children under five years old in Indonesia was categorized as short with the highest percentage in East Nusa Tenggara Province and West Sulawesi Province (Kementerian Kesehatan RI, 2017). When compared to several neighboring countries, the prevalence of children under five years old with short stature in Indonesia is higher compared to Myanmar (35\%), Vietnam (23\%), Malaysia (17\%), Thailand (16\%), and Singapore (4\%). Global Nutrition Report of 2014 showed that Indonesia was included in 17 countries from 117 countries, which had three nutritional status in children under five years old, namely stunting, wasting, and overweight (Kementerian Kesehatan RI, 2017). Prevalence of short stature in children between 0-59 months old in Bengkulu Province was 23.9\%. This number showed that children under five years old in Bengkulu Province experienced chronic nutrition problem (prevalence $>20 \%$ ) (Kementerian Kesehatan RI, 2017).

Numerous studies found that the risk factors for stunting are history of Low Birth
Weight (LBW), maternal education, maternal knowledge regarding malnutrition, and family type (Mardani, 2015), infectious disease and family economy \& social status (Pacheco et al. . 2017), health education (Kartini et al., 2016). However, the direct cause of stunting was insufficient consumption of macro- and micronutrients in growth period which disturb child's growth process and cause stunting (Mikhail et al,2013). Beside nutrition consumption factor, child body need nutrient to grow and develop which include calorie source, carbohydrate, protein, fat, mineral, and vitamin. One of the most important mineral in child's linear growth is iodine.

Iodine is a micronutrient needed in thyroid hormone synthesis. Iodine deficiency cause decrease in thyroid hormone production which cause Iodine Deficiency Disorder (IDD). The most IDD prone groups are pregnant mother, lactating mother, and children (Kementerian Kesehatan RI, 2017). Iodine is important for mental and physical development and to maintain body immune system. Chronic iodine deficiency disturbs central nervous system and brain function (Shazia et al, 2012). Iodine deficiency is the main preventable cause of brain damage ( Hetzel, 2015).

The recommended iodine intake for children under two years old is $90 \mathrm{mg}$ per day (Andersson et al., 2007). Although body iodine requirement is very low, this nutrient is very needed. Iodine deficiency could cause several condition such as goiter, stillbirth, abortion, hypothyroidism, and development disorder (Andersson et al., 2005). Iodine is present in almost all body tissue and it is found in high amount in thyroid gland, breast, abdomen, liver, lung, heart, adrenal gland, and ovary. Thyroid gland synthesized thyroxine and triiodothyronine hormones. These hormones are important to maintain body metabolism and brain development (Shazia, 2012). WHO recommends that prevention of brain damage and thyroid function disorder in children because of iodine deficiency should started during pregnancy, lactating period, and the first two years of life (Andersson et al., 2005).

Report of 2013 Basic Health Research showed that prevalence of IDD in Indonesia reached $11.1 \%$ (Kementerian Kesehatan RI, 
2017). Survey of iodinized salt monitoring in Bengkulu Province in 2008 reported that out of 972 villages, $57.6 \%$ had good iodinized salt utilization, while in Bengkulu City there were $87.7 \%$ villages with good iodinized salt utilization. However, the survey result in work area of Pasar Ikan Public Health Center showed that only $25 \%$ villages had good iodinized salt utilization (Dinas Kesehatan Kota Bengkulu, 2008).

Bengkulu Province is geograpically located along Sumatera's west coast around 525 $\mathrm{km}$ with Enggano Island chain located around 90 nautical miles in Indian Ocean south of Bengkulu Province. Due to its geographical location at coastal area, Bengkulu City has the potential to produce numerous fish, shrimp, and other sea product which are known as good iodine sources. However, the rate of iodine intake in this area is still unknown. From national IDD mapping in 1996/1998, it was found that coastal area had moderate prevalence of goiter. In Maluku coastal area, endemic goiter could also be found. The interesting fact observed are the environmental factors which could cause the difference in IDD prevalence in different areas and the reason of high prevalence of iodine deficiency in coastal area which should show low prevalence (Saidin, 2009).

The main sources of iodine are food fortified by iodine, such as salt, milk product and bread, or sea food (Leung \& Braverman, 2014). Bengkulu City is surrounded by numerous fish and seafood producing coastal areas. Therefore, it was assumed that iodine consumption was high. However, the prevalence of stunting was still high. Study regarding risk factors of stunting in coastal area according to iodine intake is still limited. This study aimed to understand the iodine consumption among children under five years old in coastal area and its correlation with linear growth.

Methods

This study used cross sectional approach. The study was performed in Malabero coastal area of Bengkulu City which was the working area of Pasar Ikan Public Health Center. The study was conducted from March to July 2016. The independent variable was iodine consumption, measured semiquantitatively using Food Frequency Questionnaire (FFQ) instrument by asking all nutrition materal which were consumed by the children and then it was processed by nutrisurvey. The dependent variable was linear growth of children under five years old which was measured using Z-score of BH/A index with 2005 WHO anthropometric standard. Based from iodine consumption data, the average consumption was calculated and then the data was categorized as low iodine consumption if the intake is $<90 \%$ according to recommended dietary allowances (RDA) for particular age group. Body height was measured using microtoice with capacity of $200 \mathrm{~cm}$ and precosion of $0.1 \mathrm{~cm}$ and then Z-score was calculated according to BH/A index accordng to WHO Anthropometry. The population was all children aged 2-5 years old, totaling to 642 children distributed throughout the working area of Pasar Ikan Public Health Center (PHC) Bengkulu City. The sampling unit were children under five years old who met the inclusion criteria, namely did not posses chronic disease and normal birthweight. 73 children between 2-5 years old were acquired through purposive sampling. Analysis unit were mother with children between 2-5 years old. The data were analysed using Chi square, correlation, and linear regression.

\section{Results and Discussion}

The result in table 1 showed that $71.2 \%$ of children under five years old had less iodine intake than recommended dietary allowances ( $<90 \% \mathrm{RDA})$. The average of iodine consumption was only $102.74 \mu \mathrm{g}$ or $47.7 \% \mathrm{RDA}$ with the lowest intake was $45.9 \mu \mathrm{g}$ or $34 \% \mathrm{RDA}$ and the highest iodine intake was $144.5 \mu \mathrm{g}$ or $120.1 \%$ RDA.

Table 2 showed that distribution of iodine consumption according to gender of children under five years old was homogenous ( $p$ value $>0.05$ ) where iodine intake in most of male or female children were below recommended dietary allowances ( $<90 \% \mathrm{RDA})$. This showed that average iodine consumption in children under five years old in Malabero coastal area (working area of Pasar Ikan Public Health Center of Bengkulu City) was low. The average iodine intake was $102.74 \mu \mathrm{g}$ or $47.7 \% \mathrm{RDA}$ with lowest intake of $45.9 \mu \mathrm{g}$ or $34 \% \mathrm{RDA}$ and highest iodine intake of $144.5 \mu \mathrm{g}$ or $120.1 \%$ 
Table 1. Iodine Consumption of Children Under Five Years

\begin{tabular}{ll}
\hline Iodine Consumption Characteristics & $\mathrm{n}=73(\%)$ \\
\hline Sufficiency of iodine consumption (\%) & \\
Low $(<90 \%$ RDA) & $52(71.2)$ \\
Sufficient $(\geq 90 \%$ RDA) & $21(28.8)$ \\
\hline
\end{tabular}

Iodine consumption, $\mu \mathrm{g}$ (average $\pm \mathrm{SD}$ ); min-max 102.74 $\pm 32.74 \mu \mathrm{g} ; 45.9-144.5 \mu \mathrm{g}$

Percentage of iodine sufficiency, \% AKG (average \pm SD); min-max

Source: Primary Data

Table 2. Iodine Consumption According to Gender of Children Under Five Years

\begin{tabular}{llll}
\hline Genders & $\begin{array}{l}\text { Iodine consumption (\%RDA) } \\
\text { Sufficient } \\
(\geq 90 \% \mathrm{RDA})\end{array}$ & $\begin{array}{l}\text { Low } \\
(<90 \% \mathrm{RDA})\end{array}$ & $\mathrm{P}$ \\
\hline Male & $12(32.4)$ & $25(67.6)$ & 0.08 \\
Female & $9(24.3)$ & $27(73.0)$ & \\
\hline
\end{tabular}

Source: Primary Data

Table 3. Linear Growth of Children Under Five Years

\begin{tabular}{ll}
\hline Linear growth characteristic (BH/A) & $\mathrm{n}=73(\%)$ \\
\hline Linear growth disorder, $\mathrm{n}(\%)$ & $39(53.4 \%)$ \\
Short/Very Short & $34(46.6 \%)$ \\
Normal & $-1.09 \pm 0.502 ;-3.64-0.21$ \\
\hline BH/A Index, Z score (average \pm SD); min-max &
\end{tabular}

Source: Primary Data

Table 4. Correlation between Iodine Consumption and Linear Growth of Children Under Five Years

\begin{tabular}{llll}
\hline \multirow{2}{*}{ Iodine Consumption } & \multicolumn{2}{l}{ Linear Growth } & \multirow{2}{*}{ P value } \\
\cline { 2 - 3 } & Stunting & Normal & \\
\hline Low & $38(73.1)$ & $14(26.9)$ & \multirow{2}{*}{0.0001} \\
Sufficient & $1(4.8)$ & $20(95.2)$ & \\
\hline
\end{tabular}

Correlation coefficient $(r)=0.73$; $p$ value of linear regression $<0.005$

Source: Primary Data

RDA. Average body iodine requirement was $1-2 \mu \mathrm{g} / \mathrm{kg}$ body weight and according to RDA, for 1-12 years old age, intake of $£ 120 \mu \mathrm{g} /$ day/ $\mathrm{kg}$ was considered low and sufficient if $>120$ $\mu \mathrm{g} / \mathrm{day} / \mathrm{kg}$ body weight per day (Kementerian Kesehatan RI, 2017). The result of the study found that $71.2 \%$ of children under five years old with iodine intake less than recommended dietary allowances ( $<90 \%$ RDA). Actually, body iodine requirement is very low. According to Indonesian $\mathrm{RDA}$, iodine requirement according to age groups are $90 \mu \mathrm{g} /$ day in children between 0-6 months old and $120 \mu \mathrm{g} /$ day in children between 7-11 months old and 1-7 years old (Kementerian Kesehatan RI, 2017). However, it was found that most of children under five years old in Malabero coastal area in Bengkulu City did not have sufficient iodine intake although Bengkulu City is a coastal area with numerous sea food sources.

According to gender, the result showed that both female (73\%) and male (67.6\%) children had low iodine intake. Insufficiency of iodine intake can disturb growth because iodine is needed in thyroid hormone production which plays a role in growth process beside Growth Hormone (GH) and Insulin-like Growth Factor (IGF-1). Thyroid hormone regulates body metabolism and is important for most of body organ system. Normal thyroid status is needed 
for normal growth and nervous development in children (Vonaesch et al., 2017).

The result on correlation between bone age maturity and prevalence of stunting in elementary school-aged children in farming region in Brebes Regency showed that $42.4 \%$ children experienced delay in bone age. Delay in bone age was correlated with prevalence of stunting. Stunting was more prevalent in student with delayed bone age (42.9\%) compared to student with normal bone age (5.3\%). Chi Square test showed that there was a significant relationship $(\mathrm{p}=0.001)$ (Kartini, 2016). The result of several studies proved that factors which affect IDD were iodine intake deficiency, geographical factor, environmental factors: goitrogenic agent consumption, industrial waste pollution such as lead and mercury, trace element factor, and nutrition factor (energy-protein deficiency and vitamin deficiency) (Saidin, 2009).

Table 3 showed that $53.4 \%$ of children under five years old in Malabero coastal area in Bengkulu City experienced linear growth disorder (short and very short according to $\mathrm{BH} / \mathrm{A}$ index $\mathrm{Z}$ score $<-2 \mathrm{SD}$ ). Average $\mathrm{Z}$ score according to $\mathrm{BH} / \mathrm{A}$ index was $-1.09 \mathrm{SD}$ with lowest $\mathrm{Z}$ score $-3.64 \mathrm{SD}$ and highest $\mathrm{Z}$ score $0.21 \mathrm{SD}$. The result showed very high prevalence of linear growth disorder which must be managed because it showed a very serious problem (WHO, 2010). The result also showed that Pasar Ikan Community Health Center need to improve their management and plan strategies to manage nutrition problems, especially regarding stunting. This is needed to achieve the primary objective of 2015-2019 Intermediate Term Development Plan, namely to decrease the prevalence of stunting (short and very short) in children under two years old to become 28\% (Kementerian Kesehatan $\underline{\mathrm{RI}}$, 2017). This study was in line with the prevalence of stunting in children under five years old in Bangui coastal area in Sub-Saharan Africa (49\%) (Vonaesch et al., 2017). The high prevalence of stunting in coastal area was correlated poverty among fishermen families and poor environment sanitation. Prevalence of stunting was correlated with living region. A study in slum area in Botswana City showed that children living in fishermen area were significantly affected by wasting, stunting, and underweight (Mahgoup et al., 2006).

The result in table 4 showed that there were $73.1 \%$ of children under five years old with iodine intake $<90 \%$ RDS who experienced linear growth disorder and there were only $4.8 \%$ children with iodine intake $\geq 90 \%$ RDA who experienced linear growth disorder. Statistical analysis using chi square and linear regression showed that there was a correlation between iodine consumption and linear growth of children under five years old in Malabero coastal area, Bengkulu City. The correlation coefficient was $0.73 \%$ which showed that there was a strong positive linear relationship between iodine consumption and linear growth.

Stunting is the result of chronic nutrition deficiency which inhibits linear growth. Growth failure could be caused by inadequacy of one or more macro- or micronutrient. People in developing countries usually experience microutrient deficiency in their daily intake (Branca \& Ferrari, 2002). Deficiencies in macronutrients, such as energy sources and protein and micronutrients, particularly in growth stage, could disturb growth process which result in stunting (Mikhail et al, 2013). Correlation coefficient of 0.73 showed that there was a strong relationship between iodine consumption and linear growth disorder. This was in line with a study by Devi (2012) which found that there was a correlation between iodinized salt utilization and linear growth.

During growth process, iodine is very much needed to help produce triiodothyronine (T3) and tetraiodothyronine (T4) compounds. If the compunds' concentration is low because of inadequate iodine intake, basal metabolic rate would be low, which in turn would disturb growth and development. Iodine is used in thyoxine hormone synthesis. Thyroxine works by increasein the metabolic rate of all cells (Devi, 2012). Low iodine consumption cause thyroid gland unable to secrete thyroid hormone. Thyroid hormone has very important role in growing baby and children in numerous metabolic processes (protein, carbohydrate, fat) and biological activities of almost all human body organs. Deficiency or excessice concentration of thyroid hormone could disturb numerous metabolic process 
and physiological activities and influence growth and development of numerous tissues, including nervous system and brain. Fetus and baby with thyroid hormone deficiency could suffer from physical deformity, mental disorder, nervous disorder, and cretinism. Cretinism is mental retardation condition accompanied by mutism, deafness, typical standing posture and gait, hypothyroidism, and short stature (Kementerian Kesehatan RI, 2017; Rohner et al., 2014). In regions with iodine shortage, low level of thyroid hormone would cause brain development disorder. More severe condition would cause cretinism. Therefore, mental ability of children and adults who lived in the region were low compared to other region (WHO, 2007).

Low iodine consumption in children under five years old in working area of Pasar Ikan Public Health Center might be followed by low intake of other nutrients such as carbohydrate, protein, and fat, because food which contain high amount of iodine are usually also contain high amount of protein e.g fish, shrimp, oyster, and seaweed. If carbohydrate and fat are not readily available for energy production, thyroxine would cause protein degradation as source of energy. Conversely, if carbohydrate and fat are present in adequate amount and there are excessive amount of amino acids in extracellular fluid, thyroxine would increase the rate of protein synthesis. When thyroid hormone is sufficient, the effect of growth hormone in hypophisis towards growth become significant. The result of study in the coastal area of Palu City, Central Sulawasi Province showed that low protein consumption could increase the probability to acquire IDD by 30.6 times compared to individual without IDD (Patuti et al., 2010). Bone growth process is very influenced by nutritional status. Optimal bone growth could be accomplished from carbohydrate and fat according to their requirement, and the presence of protein synthesis and normally secreted thyroxine hormone by thyroid gland (Setijowati, 2005).

\section{Conclusions}

Iodine consumption in both male and female children under five years old in Malabero coastal area, Bengkulu City, are categorized as low according to RDA. Although the children lived in coastal area, iodine sufficiency was not guaranteed. This low level of iodine consumption was correlated with linear growth disorder. Statistical analysis showed positive linear pattern which meant that lower iodine intake caused lower $\mathrm{Z}$ score of $\mathrm{BH} / \mathrm{A}$ index.

\section{References}

Andersson, M., de Benoist, B., Delange, F., \& Zupan, J., 2007. Prevention and Control of Iodine Deficiency in Pregnant and Lactating Women and in Children Less Than 2-yearsold: Conclusions and Recommendations of the Technical Consultation. Public Health Nutrition, 10(12A), pp.1606-1611.

Andersson, M., Takkouche, B., Egli, I., Allen, H.E., \& Benoist, B.D., 2005. Current Global Iodine Status and Progress over the Lastdecade towards the Elimination of Iodine Deficiency. Bulletin of the World Health Organization, 83(7), pp.518-525.

Branca, F., Ferrari, M., 2002. Impact of Micronutrient Deficiencies on Growth: The Stunting Syndrome. Ann Nutr Metab, 46(suppl 1), pp.8-17.

Devi, M., 2012. Hubungan Penggunaan Garam BerIodium Dengan Pertumbuhan Linier Anak. Jurnal TIBBS (Teknologi Industri Boga dan Busana), 3(1), pp.52-57.

Dinas Kesehatan Kota Bengkulu. 2008. Profil Kesehatan Kota Bengkulu. Bengkulu.

Erna, K., Rahardjo, S., \& Sistiarani, C., 2017. Multilevel Intervention Model to Improve Nutrition of Mother and Children in Banyumas Regency. Jurnal Kesehatan Masyarakat, 12(2), pp.261-269.

Hetzel, B.S., 2015.Towards the Global Elimination of Brain Damage due to Iodine Deficiency - the Role of the International Council for Control of Iodine Deficiency Disorders. International Journal of Epidemiology, 34(4), pp.762-4.

Kartini, A., Suhartono, Subagio, H.W., Budiyono, Emman, I.M., 2016. Kejadian Stunting dan Kematangan Usia Tulang Pada Anak Usia Sekolah Dasar di Daerah Pertanian Kabupaten Brebes. Jurnal Kesehatan Masyarakat, 11(2), pp.96-103.

Kementerian Kesehatan RI, 2017. Hasil Pemantauan Status Gizi (PSG) Tahun 2016. Jakarta: Direktorat Gizi Masyarakat Direktorat Jenderal Kesehatan Masyarakat Kementerian.

Leung, A.M., \& Braverman, L.E., 2014.Consequences of Excess Iodine. Nat Rev Endocrinol, 10(3), pp.136-142.

Mahgoup, S.E., Nyepi, M., Bandeke, T., 2006. Factor Affecting Prevalence of Malnutrition 
Among Children Under Three Years Old Age In Botswana. African Journal of Food Agriculture Nutrition and Development, 6(1).

Mardani, R.A.D., Wetasin, K., dan Suwanwaiphatthana, W., 2015. Faktor Prediksi yang Mempengaruhi Terjadinya Stunting pada Anak Usia di Bawah Lima Tahun. Jurnal Kesehatan Masyarakat, 11(1), pp.1-7.

Mikhail, W.Z.A., Hassan, M,.Sobhy, H.M., El-sayed, H.H., Khairy, S.A., Abusalim, H.Y.H., Saemy, M.A. 2013. Effect of Nutritional Status on Growth Pattern of Stunted Preschool Children in Egypt. Academic Journal of Nutrition, 2(1), pp.01-09.

Pacheco, P.I., Sinaga, M., 2017. Health, Food Consumption, Social Economy, and Stunting Incidency in Timor Leste. Jurnal Kesehatan Masyarakat, 13 (2), pp.261-269.

Patuti, N., Sudargo, T., Wachid, D.N., 2010. Faktorfaktor yang Berhubungan dengan Kejadian GAKY pada Anak Sekolah Dasar di Pinggiran Pantai Kota Palu Provinsi Sulawesi Tengah. Jurnal Gizi Klinik Indonesia, 7(1), pp.17-26.

Rohner, F., Zimmermann, M., Jooste, P., Pandav, C., Caldwell, K., Raghavan, R., Raiten, D.J., 2014. Biomarkers of Nutrition for DevelopmentIodine Review. The Journal of Nutrition, 144(8), pp.1322S - 1342S.

Saidin, S., 2009. Hubungan Keadaan Geografi dan Lingkungan dengan Gangguan Akibat Kurang Yodium (GAKY). Media Litbang Kesehatan, 19 (2), pp.101-108.

Setijowati, N. 2005. Hubungan Kadar Seng Serum dengan Tinggi Badan Anak Sekolah Dasar Penderita GAKY. Jurnal Kedokteran
Brawijaya, 21(1), pp.22-28.

Shazia, Q., Mohammad, Z.H., Rahman, T., \& Shekhar, H.U. 2012. Correlation of Oxidative Stress with Serum Trace Element Levels and Antioxidant Enzyme Status in Beta Thalassemia Major Patients. Hindawi, 2012, pp.1-7.

Sudiman, H., 2008. Stunting atau Pendek: Awal Perubahan Patologis atau Adaptasi Karena Perubahan Sosial Ekonomi yang Berkepanjangan?. Media Litbang Kesehatan, 8(1), pp.33-43.

Vonaesch, P., Tondeur, L., Breurec, S., Bata, P., Nguyen, L.B.L., Frank, T., Farra, A., Rafai, C., Gilles-Vernick T., Gody, J.C., GouandjikaVasilache, I., Sansonetti, P., \& Vray Met., 2017. Factors Associated with Stunting in Healthy Children Aged 5 Years and Less Living in Bangui (RCA). Plos One, 12(8), pp. $1-17$.

Welasasih, B.D. \& Wirjatmadi, R.B., 2012. Beberapa faktor yang Berhubungan dengan Status Gizi Balita Stunting. The Indonesian Journal of Public Health, 8(3), pp.99-104.

World Health Organization, 2010. Nutritional Landscape Information System (NLIS) Country Profil Indicators: Interpretation Guide, 2010.

World Health Organization, 2007. Assesment of Iodine Deficiency Disorders and Monitoring Their Elimination. Third edition, Geneva: WHO, pp. 6-7. 